\title{
The Administration of Small-Scale Economies in the Cross- Border Trade in Southeast Asia
}

\author{
Submitted 13/02/20, $1^{\text {st }}$ revision 01/03/20, $2^{\text {nd }}$ revision $27 / 03 / 20$, accepted $14 / 04 / 20$
}

\author{
Hadi Suratman ${ }^{1}$, FX. Adji Samekto ${ }^{2}$, Nanik Trihastuti ${ }^{3}$
}

\begin{abstract}
:
Purpose: This research aims to reveal that the servitude for economic interest in cross border trade zone can be applied in Southeast Asian countries. This trade cooperation includes the right to carry out certain actions in a country's territory as a place of trade for their foreign citizens.

Approach/Methodology/Design: This study was conducted by using the field research and analyzed with descriptive analysis regarding the establishment of inter-state trade zones in the border regions of Malaysia and Indonesia.

Findings: The results showed that managing the border region it is required to be emphasized by using servitude for economic interest to establish special trade zone for the creation of social justice in the border region. The establishment of a Special Area of Cross Border Trade, as that in Serikin market in Serawak, Malaysia, can be administratively used an alternative in managing the socio-economic border relations between Indonesia and Malaysia. There are several issues that must be examined as the implications of the establishment of border trade zones.

Practical Implications: It is necessary to make an agreement on a special cross-border trade area to complement BCA and the BTA, in form of the Border Area Agreement (BAA).

Originality/value: The trade area in the Serawak border is part of the acculturation of border communities, which requires special consideration in terms of management, legal rights and national jurisdiction. In addition, this kind of trade area is not formed by the Border Cross Agreement (BCA) and the Border Trade Agreement (BTA).
\end{abstract}

Keywords: Servitude, sovereign rights, special trade zone, cross-border trade, IndonesiaMalaysia.

JEL codes: F18.

Paper Type: Research article.

\footnotetext{
${ }^{1}$ Diponegoro University, Semarang, Indonesia, e-mail: hadisuratman0@gmail.com

${ }^{2}$ Diponegoro University, Semarang, Indonesia, e-mail: adjisamekto@yahoo.com

${ }^{3}$ Diponegoro University, Semarang, Indonesia, e-mail: naniktrihastuti@lecturer.undip.ac.id
} 


\section{Introduction}

Border trade in land border between Indonesia and Malaysia in Borneo Island was actually formed by cross-border traders, long before the birth of Border Cross Agreement (BCA) and the Border Trade Agreement (BTA) in 1970. Special agreements are in the jurisdiction of Malaysia, as in the context of the Serikin market in the state border between Sarawak, East Malaysia and West Kalimantan, Indonesia. However, the existence of such traditional markets is not based on specific regulations that are binding either in the form of laws, or through bilateral agreements. The absence of binding regulations makes the formation of the Serikin market a trading area not because of the desires of the two countries of Indonesia and Malaysia. Regarding the trade area, Government Regulation of the Republic of Indonesia Number 34/2019 Concerning Border Trade stated that border trade can only be carried out in certain places and/or regions that have been designated as border trade areas which shall be carried out based on bilateral agreements in accordance with statutory provisions. This clause needs to make a bilateral agreement related to the border trade places and territories.

Hence, this research aims to reveal that the servitude for economic interests in cross border trade zone which can be applied in Malaysia and Indonesia boundary management context. The establishment of special zones for cross-border trade in certain contexts commonly adopts the legal provisions of economic areas with servitude for various purposes (Satterthwaite, 2005; Munro, 2005). Servitude can emerge when in the territory of a country there are legal rights of other countries. A country that enjoys servitude has the right to do an act in another country's territory, such as to pass in another country (Adolf, 2002). Servitude economic area according to international law is the territory of another country that can be used by a country for its economic interests through bilateral agreements.

However, the presence of Serikin market is not through bilateral agreements, nor is it a region with servitude for Indonesia, but the area is deemed to be like the servitude intended for Indonesia. In relation to its strategic location, cross-border trade in Serikin, and its implications for bilateral relations, security and border politics, has become a special study in Southeast Asian studies (Awang et al., 2013; Djafar et al., 2016; Hutasuhut et al., 2018; Abao, 2020; Awang et al., 2017; Sulehan et al., 2013; Hsia, 2019; Azmi et al., 2017). However, much of the focus of previous studies has only been on relations between border populations and informal trade relations, and does not specifically address the existence of such regions in terms of international law and regional economics at large. The existence of such informal trade is important for border population in terms of economic and social relations.

However, it is highly dependent on national policy and legal support. The absence of a legal basis regarding the existence of this zone basically does not support the role of markets in the border economy and cultural relations between countries (Little et al., 2015; Peberdy, 2002). For this reason, this study offers the implementation of 
servitude as state recognition in small scale economies in the cooperation among border communities. This study henceforth seeks to analyze servitude in the establishment of a special area of cross border trade in Sarawak of East Malaysia and West Kalimantan, Indonesia by taking a case study of the Serikin trade area located between the two countries.

\section{Methodology}

This article is the result of field research conducted in Serikin, Serawak on 14-16 April 2019. The research approach used is qualitative, using data collection methods in the form of interviews and observations. Interviewees included the Governor, the Chamber of Commerce and Industry, the Ministry of Foreign Affairs for Southeast Asia, officials at the border, Trans-Border Traders from the Indonesian border and a visit to a traditional market in Serikin Malaysia. The results of the field research are adjusted with the literature research, and then analyzed with descriptive analysis.

\section{Border Trade and Implementation of Servitude in International Law}

The Special Area of Border Trade in this study is an area established for border trade activities between Indonesia and Malaysia, which is regulated in the form of bilateral cooperation agreements between Indonesia and Malaysia. In the border of IndonesiaMalaysia especially in West Kalimantan and Sarawak is unique due to the existence of a traditional trading area or market in the Malaysian region, in the Serikin District, to accommodate trading between Indonesian people who live near the border, as well as people from outside Kalimantan. In the Serikin market, all goods are imported from Indonesia, both in the form of food products, clothing, daily necessities, household appliances, and other commodities. Indonesian people who trade in Serikin can get a welcome from the Malaysian community, even received protection from the Serikin community. The openness of the Malaysian side to Indonesian traders is from the strong social and cultural relations.

On the other hand, the way to enter Indonesian traders is only to use a Cross-Border Pass, or a Cross-Border Permit Card, and some only use an identity card. Indonesian traders can carry as many goods as possible without having to be taxed by the Malaysian side. Even though they should be limited to RM600, goods coming from Malaysia entering Indonesia are limited to only RM600, and prohibited by the Indonesian side. The existence of Indonesian people who trade in Serikin Malaysia is very beneficial for Malaysians. This is because the goods needed by Malaysians can be sought at the Serikin market at low prices and have good quality. Indonesian products are considered to be of good quality based on comparisons with goods in the Kuching market, all of which are imported from China, India, Vietnam and Thailand. This market in turn can be used as a gateway to accommodate the economic activity and trade with neighboring countries (Zein, 2016). 
Every country has a strategy to advance and prosper society in economic matters. Indonesia is a country that embraces the concept of a welfare state (Friedmann, 1985). The welfare state is briefly defined as a state in which the state government is assumed to be responsible in guaranteeing the minimum standard of living for every citizen, so that many politicians want the creation of a welfare state as a form of state which is considered capable of prospering its people. Indonesia is a welfare state even though it is not explicitly stated in the 1945 Constitution of the Republic of Indonesia. This means that with the example of the Constitutional Court ruling there is no doubt that Indonesia is a welfare state, the Court's decision above acts as a constitutional interpretation of a number of issues relating to or related to the idea of the welfare state according to the 1945 Constitution of the Republic of Indonesia which is practiced in Indonesia (Palguna, 2019). According to Pierson, the term of welfare, in a welfare state, contains at least three subclassifications. First, social welfare refers to the collective acceptance of welfare. Second, economic welfare, refers to security guarantees through the market or the formal economy. Third, state welfare, refers to the guarantee of social welfare services through state agents (Palguna, 2019).

Furthermore, in international law, it was known as the right of servitude. This right is often exercised in European countries. The right of servitude is the right of a country for economic progress, to be able to build facilities in other countries (Klein, 1993). For example, France in order to improve railroad transportation makes the UK territory used for the construction of railroads, with the agreement from the UK. Likewise, for a country located on a continental plateau, the railroad connecting from one country to another is part of the accommodation of interests and economic needs between countries. According to Jean Bodin (1992), there are 4 main characteristics of national sovereign. The first is permanent, meaning sovereignty that remains as long as the country is still standing. The second is original, meaning that sovereignty does not originate from other higher powers. The third is unanimous meaning that sovereignty is the only supreme power, and the fourth is unlimited referring to the highest nature of sovereignty (Jones, 2002).

Servitude, according to Vali (1958), is a condition where a person lacks freedom, especially to determine actions or ways of life. Servitude arises when the territory of a country is a legal right of another country. Servitude are rights for other countries to use an area for certain activities such as economic activities. Countries that enjoy servitude have the right to commit acts in the territory of other countries. For example, a country has the right to pass in another country. Moreover, Oppenheim's (2018) theoretical perspective proposed four kinds of servitude (positive, negative, military and economic servitudes). In this context, Positive Servitude or Affirmative/Active-Positive Servitude, is servitude which gives a country the right to carry out certain actions in other countries, such as building a railroad, building a customs office, and others. Included in this form is the right of one country to ask another country so that its citizens are allowed to take certain actions, for example fishing in certain parts of the sea. 
Positive Servitude could be followed up through regional cooperation by Indonesia and Malaysia to increase the regional cooperation related to servitude. Indonesia and Malaysia have made the Sosek Malindo agreement, which is a cooperation in the social and economic fields. However, the cooperation applied in this agreement is only a mutual understanding which does not specifically regulate cross-border trade outside the provisions of bilateral agreements.

Servitude become international habits, and have become part of international law. This has arisen because in the territory of a country there is a legal right of another country. Every country that has civil law recognizes servitude. Indonesian Civil Law regulated in Burgerlij Wetboek contained in article 674 states that serving the yard is a burden that is given to the yard belonging to one person, to be used by and for the happiness of the yard belonging to another person. It is clear that long before Indonesian independence in 1945, the right of servitude was in effect in the Dutch East Indies. Nevertheless, the Dutch law adopted into Indonesian law did not mean to clearly specify the laws to include the right of other countries.

Servitude are born because of the national interests of a country, both interests related to law, politics, military or economy. Servitude for the sake of the economy are widely applied by countries whose economic needs are in other countries (Rudnyckyj, 2004). According to Oppenheim (2018), economic servitudes are the right to the goals or interests of the trade, border traffic and other economic rights, customs clearance in certain regions or economic zones, or to sail, and to build transportation facilities in other countries (Adolf, 2002). On the border of West Kalimantan with Sarawak requires economic servitude to regulate the informal trade among small and medium economies. The interests of the border economy should certainly be seen more rationally and to accommodative to local interest, by establishing economic facilities and infrastructure to encourage the mobility and business transactions. The facility can be in the form of cross-border between the two countries, such as cross-border post and cross-border checkpoint. This facility can still be developed in relation to import duties and excise for both countries.

The border regions of the two countries which are located along the West Kalimantan with Sarawak certainly are not only based on unilateral facilities, but a real balance must be considered. This effort is to balance the economic disparity between the two border regions. Transportation and infrastructure in Malaysian border have been well developed, which facilitate the mobility of goods and people and border monitoring. On the Indonesian side, the lack of infrastructure that supports mobility has made it prone to legal problems by utilizing illegal pathways in tropical forests such as smuggling, illegal logging, human trafficking, and drugs. Hence, servitude can be exercised by the Indonesian government in Malaysia, such as to build economic facilities in the country of Malaysia. This is in line with some international examples, such as the servitude exercise between France and Sardinia in the case of the Free Zone of Savoy and the District of Gex (Alxehurst, 1970). 


\section{Economic Servitude for Accelerating Border Economic Growth}

Malaysia and Indonesia economic relationship in border areas, especially in the Serikin market, indirectly provides its own advantages from international trade carried out by the Provincial Government of West Kalimantan. The trade carried out by the border communities in the Serikin market is really profitable. However, transactions through the West Youtan post are still considered less competitive for Indonesia, due to the imbalance between the value of exports to and imports from Malaysia. As an illustration, there are several entrances to Malaysia. Commodities exported by Indonesia to Malaysia can be traded directly in small quantities at some border posts such as Jagoi Babang. Meanwhile, in several other posts, commodity trading may only be carried out by large exporters and importers, which are not directly carried out by border communities.

To increase the income and trade scale of border communities, the government hence should be able to immediately establish a special trade area in the Serikin district. The involvement of more countries in regulating cross-border trade activities is very important. Data from the West Kalimantan Statistics Agency shows the quantity of commodity exports of $1,097,403,262 \mathrm{~kg}$ to Malaysia in all lines, both cross-border posts, provincial ports and airports. Of this amount, only 2,099,487 kg of commodities were traded at the Jagoi Babang cross-border post. This amount is only 0.19 percent of the total export of the province. This shows the suboptimal export-oriented economic activities in the border region, especially in Jagoi Babang.

In addition, data from the Entikong cross-border post also contributed to around 0.8 percent of the total weight of the province's export commodities. Of the several cross-border posts along the border of Indonesia and Malaysia, there are two posts in West Kalimantan, which are Jagoi Babang and Entikong. Both are used for Malaysian export routes. Most of the export commodities at the Jagoi Babang post are tobacco, textile fibers and paper goods, while for other goods are through Entikong post. In total, these two posts contributed to about 1 percent of the province's export quantity. In the FOB value, these two posts accounted for around 26 million USD, of the total FOB value of the province of 623,422 million USD, or equivalent to 4.17 percent (Table 1). In terms of export policy, Indonesia does not impose excise duties on the tobacco trade and neither does the tax in the Jagong Babai post, which is mostly done by individuals. Whereas the export of other commodities which are subject to excise must be carried out by business entities in the Entikong post. Pos Entikong handles 57 types of export commodities which are exported to regions in Malaysia. Trade and export-import activities at the Entikong post are more formal and procedural, compared to those at the Jagong Babai post. In terms of requirements, the Entikong post is stricter than the Jagong Babai post, which allows border crossings with a Cross-border Card, compared to the Entikong post that requires a passport. The trade at the Jagong Babai post seem informal and target small-scale economic activities. Most of the goods at this post are transacted at the Serikin market, Sarawak. 
Table 1. West Kalimantan Export Value on the Loading checkpoint of 2016

\begin{tabular}{|l|l|l|l|}
\hline No & Checkpoint & Net Weight $(\mathbf{k g})$ & FOB Value (US\$) \\
\hline 1 & Pontianak & $612,367,866$ & $458,981,669$ \\
\hline 2 & Kendawangan & $388,759,236$ & $101,868,032$ \\
\hline 3 & Namga Badau & $55,783,650$ & $33,102,217$ \\
\hline 4 & Jagoi Babang & $2,099,487$ & $13,461,250$ \\
\hline 5 & Entikong & $8,095,627$ & $12,843,498$ \\
\hline 6 & Telok air & $28,810,000$ & $2,493,582$ \\
\hline 7 & Ketapang & $1,485,790$ & 594,316 \\
\hline 8 & Supadio & 1,606 & 78,345 \\
\hline & Total & 1.097 .403 .262 & $623,422,909$ \\
\hline
\end{tabular}

Source: 2016 Official Statistics of West Kalimantan Central Bureau of Statistics.

In this context, the implementation of servitude is to revitalize and increase the contribution and role of traditional markets for groups in Indonesia's border regions and to increase cross-border tourism. Serikin Market is a traditional market in the territory of Malaysia. As a traditional market, the Serikin market is quite advanced compared to other traditional markets on the Indonesian border. Supporting factors for this market competitiveness are security, distance and commodity variance. This market has a big influence on the Indonesian population at the border both economically and socially. On this basis, the government needs to use servitude in this region to increase the contribution of the Serikin market to the social and economic life of both nationalities in the border region. In addition, the government needs to revitalize traditional markets in Indonesia's border regions to improve the lives of border residents.

From a social perspective, activities in the Serikin market are carried out freely and informally by the two nationalities in connection with ethnic, cultural and social similarities. Because commodities from Indonesia are highly dependent on this market, Indonesian traders freely carry commodities without official documents, while Malaysian citizens are not permitted to export to Indonesia without official documents. The management of economic activities through servitude in the region better economic and social effects for both regions implies that the administration of Serikin market has a positive effect in resolving border issues in terms of politics, security and supervision of illegal activities. Economic transactions in the Serikin market are also carried out by former Indonesian workers. This shows that the presence of economic facilities in the border region can improve employment patterns and economic behavior for both regions. For Indonesians, this kind of market can increase their income and economic activity. Malaysia's competitive advantage in managing markets in the border region requires the need to implement servitude's rights to increase economic activities for the benefit of Indonesia.

From the security side, the recognition of border economic activities and their strengthening through the implementation of servitude can reduce illegal activities that have been a serious problem in the border regions of the two countries. 
Strengthening regulations and facilitating small-scale cross-border transaction policies can reduce criminal activity, timber theft, smuggling and cross-border crime. Therefore, to better guarantee the welfare of border communities, it is necessary to establish a Special Cross-Border Trade Area with servitude economic rights, both in the territory of Malaysia and of Indonesia through bilateral cooperation.

\section{Conclusion}

The establishment of a Special Area of Cross Border Trade, as that in Serikin market in Serawak, Malaysia, can be legally used an alternative in managing the border between Indonesia and Malaysia. From a social perspective, activities in the Serikin market are carried out freely and informally by the two nationalities in connection with ethnic, cultural and social similarities. The implication of servitude for economic interests to establish a special trade zone is to ease for both governments of Indonesia and Malaysia in managing and controlling cross-border activities and border region in terms of politics, security and supervision of illegal activities. In the economic context, the presence of a special trade zone in the border region can improve employment patterns and economic behavior for both regions.

From the security side, the recognition of border economic activities and their strengthening through the implementation of servitude can reduce illegal activities that have been a serious problem in the border regions of the two countries. Strengthening regulations and facilitating small-scale cross-border transaction policies can reduce criminal activity, timber theft, smuggling and cross-border crime. As a role model, a special trade zone is carried out directly by the border community. For both governments, the establishment of such special trade zone can be done through formal cooperation and bilateral agreement. The study concluded that the trade area at the Serawak border with Indonesia is part of the acculturation of border communities, which requires special consideration in terms of management, legal rights and national jurisdiction. Since, the trade activities are not formed by the Border Cross Agreement (BCA) and the Border Trade Agreement (BTA), it is necessary to make an agreement on a special cross-border trade area to complement BCA and the BTA, in form of the Border Area Agreement (BAA).

\section{References:}

Abao, A.S. 2020. Cross-Border Migration in the Border Area of Jagoi Babang, Indonesia with Serikin, Sarawak, Malaysia: A Case study of Indonesian Traders at Serikin Market. Sarawak, Malaysia-Opportunities and Challenges.

Adolf, H. 2002. Aspects of the State in International Law. Jakarta, Raja Grafindo Persada. Alxehurst, M. 1970. Modern Introduction to International Law. George Allen and Unwin. Awang, A.H., Bakar, N.R.H.A., Sulehan, J., Abdullah, M.Y.H., Liu, O.P. 2017. MalaysiaIndonesia informal cross border trade: A case study of Serikin, Bau District, Sarawak. Geografia-Malaysian Journal of Society and Space, 9(1).

Awang, A.H., Sulehan, J., Bakar, N.R.A., Abdullah, M.Y., Liu, O.P. 2013. Informal cross- 
border trade Sarawak (Malaysia)-Kalimantan (Indonesia): A catalyst for border community's development. Asian Social Science, 9(4), 167.

Azmi, A., Ibrahim, N., Idris, A.K.M., Ahmad, Z., Nor, N.M. 2017. Cross Border Shopping from the Perspective of Domestic Tourists in Padang Besar, Perlis. European Journal of Economics and Business Studies, 3(1), 25-31.

Bodin, J. 1992. On Sovereignty. Cambridge University Press.

Djafar, F., Hassan, M.K.H., Husaini, D.H. 2016. Informal agricultural trade and trans-border farmers between Malaysia and Indonesia. The Journal of Developing Areas, 50(4), 19-37.

Friedmann, L.M. 1985. The Legal System: A Social Science Perspective. New York, Russel Sage Foundation.

Hsia, J.T.G. 2019. Trade History and Kinship Attribute to the Continuity Towards Goods Smuggling to the Border Community in Sarawak-West Kalimantan: Case Study in Lubok Antu-Badau Border. Malaysian Journal of Social Sciences and Humanities (MJSSH), 4(6), 45-55.

Hutasuhut, I.J., Usop, H., Zaidi Adruce, S.A., Sabil, S., Kasa, M. 2018. Examining Knowledge Transfer Using Seci Model as Lenses: A Study of Interaction among Local Malaysian Entrepreneurs and Indonesian Cross-Border Entrepreneurs in Cross-Border Serikin Weekend Market. Global Business and Management Research, 10(2).

Jones, T. 2002. Modern Political Thinkers and Ideas: An Historical Introduction. London, Routledge.

Klein, M. 1993. Introduction: Modern European expansion and traditional servitude in Africa and Asia. Breaking the chains: Slavery, bondage, and emancipation in modern Africa and Asia, 3-36.

Little, P.D., Tiki, W., Debsu, D.N. 2015. Formal or informal, legal or illegal: the ambiguous nature of cross-border livestock trade in the Horn of Africa. Journal of Borderlands Studies, 30(3), 405-421.

Munro, V.E. 2005. A tale of two servitudes: Defining and implementing a domestic response to trafficking of women for prostitution in the UK and Australia. Social and Legal Studies, 14(1), 91-114.

Oppenheim, L. 2018. International law. A treatise BoD-Books on Demand, vol. 2.

Palguna, I.D.G. 2019. Welfare State vs Globalisasi (The Idea of the Indonesian Welfare State). Jakarta, Raja Grafindo Persada.

Peberdy, S. 2002. Hurdles to trade? South Africa's immigration policy and informal sector cross-border traders in the SADC. In Workshop on regional integration, poverty and South Africa's proposed migration policy, Pretoria, Vol. 23.

Rudnyckyj, D. 2004. Technologies of servitude: Governmentality and Indonesian transnational labor migration. Anthropological Quarterly, 407-434.

Satterthwaite, M.L. 2005. Crossing borders, claiming rights: using human rights law to empower women migrant workers. Yale Hum. Rts. and Dev. LJ, 8, 1.

Sulehan, J., Bakar, N.R.A., Awang, A.H., Abdullah, M.Y., Liu, O.P. 2013. Development at the Margins: Livelihood and Sustainability of Communities at Malaysia-Indonesia Borders. Sociologija i prostor/Sociology and Space, 51(3).

Vali, F.A. 1958. Servitudes of Internasional Law: A Study of Rights in Foreign Territory. Stevens and Sons Limited.

Zein, Y.A. 2016. The Political Law of Border Area Management Based on the Fulfillment of Citizens' Constitutional Rights. Tarakan, Faculty of Law, University of Borneo Tarakan. 